\title{
On the Communicative Geography of Global Sociology
}

\author{
RonALD N. JACOBS \\ ELEANOR TOWNSLEY ${ }^{1}$
}

\begin{abstract}
This article analyzes the two distinct communicative logics that inform the institutional geography and normative understanding of global sociology. The globalizing logic imagines a unitary global space that organizes sociological debate; the transnational logic envisions a series of overlapping sociological debates, often organized within a national context that is in the process of cosmopolitan, global, and transnational transformation. We argue that both logics shape communication in the sociological tradition, even if neither project is fully realized. The main challenge to global sociology, particularly in its globalizing form, is the existence of extremely influential spaces of sociological debate in North America and Europe, which reproduce the privileges of the larger and more powerful national associations. At the same time, these large, powerful national associations are becoming increasingly transnationalized, putting centre and periphery into dialogue, if in limited and uneven ways.
\end{abstract}

Résumé. Cet article analyse deux logiques communicatives distinctes qui contribuent à la géographie institutionnelle et à l'approche normative de la sociologie globale. La logique globalisante imagine un espace global unitaire qui organise le débat sociologique; la logique transnationale envisage une série de débats sociologiques imbriqués qui s'organisent souvent dans le cadre d'un contexte national, alors que le contexte national est en train de subir une transformation cosmopolite, globale, et transnationale. Nous soutenons que ces deux logiques déterminent la communication dans la tradition sociologique, même si leurs projets ne se réalisent pas. Le grand défi pour une sociologie globale, surtout sous forme globalisante, semble être l'existence des lieux de débat sociologique extrêmement puissants en Amérique du nord et en Europe, qui, tout en ayant une influence globale, tendent à reproduire les privilèges des associations nationales les plus vastes et les plus puissantes. Pourtant, ces grandes associations nationales puissantes deviennent de plus en plus transnationalisées, de façon à établir un dialogue entre centre et périphérie - mais encore une fois, selon des échanges limités et inégaux.

1. Please direct all correspondence to Eleanor Townsley, Department of Sociology, Mount Holyoke College, South Hadley, MA 01075, 413-538-2803 w, 413-533-8234 h 
$\checkmark V$ /hatever else it may be, global sociology is a communicative pro1] ject, consisting of mediated conversations and dialogues among sociologists worldwide. What is "global" about global sociology then, is not (or not only) a common object, such as globalization or planetary society; rather, it is the refashioning of cultural exchange among those who want to participate in the sociological tradition around the world. ${ }^{2}$ We offer an analytical distinction between two communicative forms to analyze this global sociological project: the globalizing form and the transnational form. On this basis, we hope to render questions about the institutional - disciplinary, national, intellectual - nature of global sociology more precise.

There are actually two competing projects of global sociology. One of these, which we call the "globalizing form of global sociology," imagines a unitary global space that organizes sociological debate. The other project is the "transnational form of global sociology," which imagines a series of overlapping sociological debates organized within a national context in the process of cosmopolitan, global, and transnational transformation.

In addition to describing and comparing the analytical and normative viewpoints of these competing perspectives, we also examine the institutional conditions that constrain and enable their respective development. In order to do this, we limit our empirical gaze primarily to a particular institution, the International Sociological Association. We recognize that this is only one global sociological organization among many. ${ }^{3}$ We also recognize that global sociology takes place in a variety of contexts, not all of which are organized in and through professional academic associations and journals. Nevertheless, by limiting our empirical analysis to specific organizations and institutions, we hope that we will be able to effectively outline the promises and limitations (both empirical and normative) of these competing projects of global sociology.

By referring to the project of global sociology, we mean to highlight simultaneously the empirical processes of cultural/material exchange

2. We limit our focus here to sociological conversations which connect to formal disciplinary organizations and people professionally recognized as sociologists. Of course, the conversation is probably a much broader one if it is understood to include the social science movement more generally.

3. There are several other institutional locations where one could examine the global model - the Institut International de Sociologie founded in 1893 to which members of the small international sociological fraternity were elected, the Association Internationale des Sociologues de Langue Française, founded in Brussels in 1958 as an organization of French-speaking sociologists from around the world, or even the American Sociological Association which has an increasingly global reach. Arguably, however, none of these has the reach of the ISA. 
taking place between sociologists, and the normative dialogue that takes this global exchange of sociology as its object. Keane (2003) used this language in his recent book on the project of global civil society, distinguishing two types of claims that emerge from globalizing communicative projects: (1) an analytical/descriptive usage, identifying the key actors, institutions, and events, to explain how this global process has come to exist in its current form; and (2) a strategic/political calculation, establishing what must be done (or avoided) to bring about the full realization of the globalizing process under discussion. Connected to the strategic/ political calculation is a precautionary empirical analysis, examining the practical efforts to establish (and resist) the globalizing process to determine the consequences of these practical efforts for bringing the empirical situation closer to (or further from) the normative ideal. ${ }^{4}$

By talking of the project of global sociology, we also hope to highlight the fact that the empirical and normative dimensions of globalizing processes do not divide neatly according to whether one is an academic or a political actor. As Beck (2006:22-23) has argued in his discussion of cosmopolitanism and globalization, the "scientific outlook" is present among NGOs, political parties, and corporations, just as it is with academics. At the same time, these actors who are able to adopt a new perspective or worldview for seeing global processes also have hopes for actual changes they might like to see occur. Their analytical orientation does not eliminate or overwrite their normative perspective, even if the two are analytically autonomous. Likewise, for academics the analytical perspective on global processes does not eliminate the normative evaluation of those processes, nor does it call into question the subjective orientation toward what is the best or the fairest form of globalizing process (nor, for that matter, does the analytical perspective always come before the other perspectives).

It seems self-evident that the project of global sociology is connected in fundamental ways to the growing interest in globalization - not only in the structures and processes of global political economy, but also in the forms of governance and other social relations that imagine ethical visions and social solidarities beyond the nation-state (Beck 2006; Ong and Collier 2005; Kurasawa 2004; Gilroy 2004; Bauman 2002; Young 2000; Appadurai 1996; Wallerstein 1974). Thus, global sociology is connected to the swirl of anxieties that underpins much of this globalization talk - worries about the intensifying hegemony of the United States,

4. It is the dialogue between analytical/descriptive research and precautionary empirical analysis that marks as distinctive those areas of social-scientific research and debate that attempt to tackle "big ideas," particularly those which claim to "grasp the whole world in thought" (Keane 2003:xi). 
concerns about deepening global inequalities, and fears about the possibilities of planetary devastation through war and/or environmental degradation.

For the question of global sociology specifically, a central issue is the dominance of the US discipline, which shapes the sociological conversation by exporting its theories, methods, and intellectual agendas in unequal relationships with academic formations in other parts of the world. There have been calls since the 1980s to indigenize sociology in places outside the United States, Europe and/or the "West" 5 (Cardoso 1986; Albrow 1987; Akiwowo 1988, 1999; Park 1988; Gareau 1988; Loubser 1988; Sanda 1988; Abaza and Stauth 1988; Dhaouadi 1990; Arjomand 2000; Kozlarek 2001). There is also a pervading sense that the large and comparatively well-funded US discipline is inward-looking in ways that ignore or reduce sociologies in other places (Armer 1987; Chase-Dunn 2005). This dominance derives in part from the sheer number of US and US-trained sociologists in the world, the comparatively longer disciplinary history in the US, the related issue of the transnational migration of sociologists to the United States (Platt 2007), and the overwhelming dominance of the United Kingdom, the United States, and the English language in international publishing (Thompson 2005) ${ }^{6}$ In the US itself, sociology seems to be divided by the internal tensions between technocratic and critical visions (Burawoy 2005; McLaughlin, Kowalchuk and Turcotte 2006), while external critics of disciplinarity (Klein 1990; 2005; Lawrence and Désprés 2004) describe the limits of the idea of any kind of separate disciplinary project for sociology.

In this context, we suggest thinking about global sociology from the perspective of its communicative geography. This perspective offers a way to conceptualize the range of possibilities for global sociology and provides standards by which to evaluate current practice. While we are interested in the institutional organization of actual and potential global sociologies, our primary goal is to ask how the communicative spaces of these projects might be organized. Therefore, we engage in the type of precautionary empirical analysis described above as the best way to make a social-scientific intervention into debate about the "big ideas of the day." Before elaborating ideal-types of the globalizing and transnational communicative logics of world sociology, however, we begin

5. "Indigenization is the countervailing force which has arisen in response to the ethnocentrism of the West, which for long has imagined that the formal rationality of modernization both provides a universal frame and a substantive cultural content, which will render local variations peripheral and irrelevant to the irresistible main direction of social change" (Albrow 1987:10).

6. Our thanks to Jennifer Platt for making this point (personal correspondence). 
with a brief discussion of the larger theoretical debates that provide their context.

\section{Public Spheres and Communicative Logics}

Our distinction between globalizing and transnational forms of communication is influenced heavily by the debates that have surrounded Habermas's theory of the public sphere (Habermas 1989, 1996; see also Calhoun 1992; Young 2000; Benhabib 1996; Cohen and Arato 1992; Gutmann and Thompson 1996; Jacobs 2000; Alexander 2006). These debates are relevant to global sociology in several ways. ${ }^{7}$ First, theories of the public sphere provide resources for thinking about how multiple and overlapping networks and associations can be connected in a common, larger space of communication. Debates about the public sphere provide a useful outline of the advantages and disadvantages of specific ways of making this larger communicative connection. Second, understandings of communicative ethics in the public sphere are useful for imagining global sociology because they relate to larger political theories about how to connect debate and action - both within a given public, and within the wider political field. In this way, theories of the public sphere provide a way of imagining how the relatively autonomous and isolated debates of intellectuals might be connected to larger public debates on matters of common concern. In short, theories of the public sphere elucidate the tradeoffs and dilemmas of different communicative forms for global sociology.

On one side of the public sphere debate are arguments, generally in agreement with Habermas, which envision a single, fully inclusive, communicative space. This is analogous to the ideal-type of the globalizing form of global sociology, which we develop in more detail below. There are several advantages of a single communicative space: first, it maximizes the likelihood that debates taking place within the single public will be translated into actions (Garnham 1992); second, it maximizes the exposure and the potential influence of voices and viewpoints in the public sphere (Jacobs 2000); third, it creates a space of common focus and common knowledge, building the shared intersubjective framework which makes conversations among strangers possible (Alexander 2006; Dayan and Katz 1992).

7. Our focus is on the different models of communicative infrastructure that have emerged in the debates about the Habermasian theory of the public sphere. We do not treat the other important debate that has surrounded this theory, which has to do with the theories of deliberation and discourse ethics (for an excellent critical discussion see Cohen and Arato 1992). 
On the other side of the public sphere debate are arguments that criticize the normative vision of a single communicative space because of the inevitability of unequal access to that space, as well as the inevitability of unequal power (both material and symbolic) within it (Eley 1992; Fraser 1992). ${ }^{8}$ These critics offer an alternative vision of overlapping communicative spaces of various sizes and particularity, which resist full incorporation into larger hegemonic publics. This is analogous to the ideal-type of the transnational form of global sociology. The general advantage of this model is that it provides a guarantee for the institutional and cultural autonomy of smaller groups and smaller publics. Empirically, it accounts for the diversity of communicative spaces we can observe even in highly homogenous societies. The main disadvantage of this model, however, is the potential for the marginalization and general invisibility of those publics that are smaller, poorer in resources, or comparatively lacking in symbolic prestige.

In what follows, we elaborate the ideal-types of globalizing and transnational forms for global sociology, discussing their strengths and weaknesses, and pointing to the institutional conditions that enable or constrain different communicative logics. We draw on a variety of examples to illustrate our argument, giving special attention to the case of the International Sociological Association.

\section{The Globalizing Forms of Global Sociology}

The ideal-type of global sociology envisions a unitary, global space for dialogue and exchange in the sociological tradition. Such a space has many potential advantages: first, it provides a focused, inclusive forum for sociologies and sociologists from around the world; second, it can offer a fair and formally democratic mechanism for representing the viewpoints and voices of different subunits and organizations, national or otherwise; third, it can provide a common framework from which to build shared global norms in the discipline. At their strongest, these common norms provide a framework for institutional innovation in sociology and across the social sciences. This kind of communicative infrastructure not only provides a space to collect and discuss local perspectives and viewpoints, but also, importantly, it allows global sociology

8. For critics like Nancy Fraser (1992), dominant groups attempted to create a unified public sphere in order to create "active consent," where they included the subordinate groups, but did so under discursive rules which favoured the dominant group. There are also empirical problems with the single-public model of communication (see Eley 1992 in particular), which suggest that empirical civil societies have always contained plural and partial publics. 
to speak in a more unified voice to external publics and clients. Finally, to the degree that such a communicative space of global sociology is premised on institutions that are not directly dependent on nations, it can identify non-national publics and clients, and construct and participate in non-national public spheres.

In its communicative geography, the globalizing form of global sociology requires regular dialogue about matters of common concern, held together through communicative institutions that are fully inclusive and broadly shared. The most likely option is a series of nested spaces of both direct and mediated communication, which operate according to different time intervals. Direct communication, during international conferences, repeats at comparatively longer intervals. At the other extreme, one can imagine Internet-based forums in which global dialogue occurs within extremely short time intervals. ${ }^{9}$ Between these two extremes are the standard forms of mediated intellectual dialogue, consisting of books, reviews, journals, and newsletters. Importantly, all of the spaces of communication are fully inclusive and representative, and provide a common attention space for all sociologists who wish to participate in the project of global sociology.

Clearly this type of fully fledged global sociology does not yet exist. Indeed, as an idea, a unitary public sphere for sociology might be seen as somewhat out of fashion. However, we think there are reasons to take seriously this vision of a fully inclusive, democratic global sociology. At the very least, this vision of a fully inclusive, democratic global sociology allows us to ask about the ways that current practice falls short, as well as the degree to which current understandings of global sociology are informed by a commitment to a globalizing communicative space.

There is evidence that this globalizing communicative logic is operating in the current organization of sociology worldwide. Here we focus on one such organization, as a case-study - the International Sociological Association, founded in 1949 with a grant from UNESCO.${ }^{10}$ As

9. An interesting example of how this might develop comes from recent experiments with Internet open peer-review in scientific journals such as Nature and Atmospheric Chemistry and Physics. As a way to supplement the standard process of blind peer-review, these journals are also posting submitted articles for open comments by scientists. The comments are posted online, and identify the author of each comment. The hope is that this process will produce a common dialogue among scientists engaged in common specialty areas. An ongoing dialogue about the successes and failures of this project can be found at http://www.nature.com/nature/peerreview/debate/index.html.

10. The following descriptions are drawn from information at the ISA website as well as from information available online from the ISA archives in Amsterdam (International Institute of Social History ). We also rely heavily on the official history of the ISA, see Platt (1998). 
a nonprofit association with scientific goals in sociology and the social sciences more generally, the ISA aims "to represent sociologists everywhere, regardless of their school of thought, scientific approach or ideological opinion, and to advance sociological knowledge throughout the world." Formally affiliated with UNESCO, the ISA boasts of its status as a nongovernmental organization with "special consultative status with the Economic and Social Council of the United Nations." Thus, in its origins, mandate, and mission, the ISA is modeled on the United Nations in general and UNESCO in particular. It is part of UNESCO's general mission

to contribute to peace and security by promoting collaboration among the nations through education, science and culture in order to further universal respect for justice, for the rule of law and for the human rights and fundamental freedoms which are affirmed for the peoples of the world, without distinction of race, sex, language or religion, by the Charter of the United Nations. ${ }^{11}$

To this end, to promote collaboration among nations through science, the ISA holds international congresses every four years, with research committees meeting every two years or more frequently. Members come from 109 different countries, and interests from across the globe are represented in the Assembly of Councils which includes both a Council of National Associations consisting of delegates from national associations (or regional congeries of interests representing several nations) and a Research Council, consisting of the delegates of the research committees. This structure parallels the model of a global parliament, imagined on the twin premises of a global public sphere and a planetary society. Note too, the formal recognition of tensions between different national sociologies of very different sizes, on the one hand, and the size of intellectual networks interested in particular subfields and topics, on the other. ${ }^{12}$ This parallels a parliamentary assembly organized to balance the interests of populations unevenly distributed in space and power.

As a practical matter, the ISA also fosters norms of global inclusiveness in several ways. First, its tiered structure of membership costs acknowledges the context of massive global economic inequality in which

11. From Article 1, section 1 of the UNESCO Constitution, signed on 16 November 1945 and coming into force on 4 November 1946 after ratification by twenty countries: Australia, Brazil, Canada, China, Czechoslovakia, Denmark, Dominican Republic, Egypt, France, Greece, India, Lebanon, Mexico, New Zealand, Norway, Saudi Arabia, South Africa, Turkey, United Kingdom, United States.

12. For a fascinating account of the evolution of the representative institutional structure at the ISA over time, especially from 1970 on, see Platt (1998:31-36). 
it operates, frankly recognizing the social fact of vastly disparate resources in different parts of the world. In addition, the ISA helps to defray the costs of participation for some visitors from less wealthy parts of the world, with Research Committees able to apply for grants on behalf of their Tier 3 participants.

Second, an effort is made to ensure that the executive officers of the Association as well as the quadrennial World Congresses are not always connected to wealthy and powerful European and North Atlantic countries, although the record shows that the western nations have dominated applications to host the World Congresses, and as a consequence, have dominated as sites for World Congresses. At the same time, however, the ISA fosters an informal institutional norm to keep the presidency and secretariat out of the United States as a counterweight to US hegemony.

Third, the ISA has a commitment to fostering regional development, supporting sociological perspectives from all over the world, and focusing the attention of world sociology on different regions. This can be seen in the national focus of selected special issues of International Sociology which present a group of papers on a particular country. There have also been initiatives to hold regional meetings prior to World Congresses to increase the likelihood of participation in the International Congress. Platt (1998:37-38) cites a series of colloquia in the recent period for "Southern Africa, East/Central Europe, East Asia, Southern Asia, Arab countries, Nordic countries, Southern Europe, Latin America, North America and Portuguese-speaking countries." She observes that "one good side of these meetings has been to stimulate some fresh regional collaborations."

Efforts to foster regional development can also be seen in the ten published regional volumes on world sociology commissioned for the 50th anniversary of the ISA in 1998 - a widely approved special initiative of the then President of the ISA, Immanuel Wallerstein. ${ }^{13}$ A more fully realized vision for a unified global sociology might have attended to intersections, overlap, and cultural traffic among regions in a more sustained manner than these separate volumes do, but the regional anniversary volumes still speak to the inclusive, representative logic of ISA norms of governance. The regional volumes also reveal that the organization has typically conceptualized the intellectual terrain of worldwide sociology as separate national pieces all over the globe, brought together by the ISA as the representative apex organization.

Without question, then, the ISA statutes bear the marks of their time of origin, with nations and national disciplines receiving organiza-

13. We thank an anonymous reviewer for making the distinction between the Presidential initiative and the general policy of the ISA. 
tional priority. Thus, while the global aspirations of the United Nations, UNESCO, and the ISA are expressed in the World Congress, the publication of international journals and efforts to internationalize hiring in the idea of a global labour market bring national boundaries, labour market, and intellectual traditions, including the power relations among nations, to the ISA. Critics of globalizing communicative forms have pointed out other disadvantages elsewhere (see Fraser 1992). For example, although Association business is conducted in multiple languages - English, Spanish and French - English is designated the official language of ISA business. English language dominance, despite institutional efforts to decentre or offset English language hegemony, is one illustration of the limits on the aspirations of the global communicative logic organized through the ISA. ${ }^{14}$

Consider another: the assumptions, aspirations, and practices of ISA publications. The flagship journal, International Sociology, describes its mission as one of publishing papers "which deserve worldwide circulation and which reflect the research and interests of the international community of sociologists." Current Sociology, the other official journal of the ISA, publishes shorter review articles around a common topic of interest, typically including authors from many different regions of the world. While both journals accept articles in any of the three official languages, they publish the articles in English, with separate abstracts in French and Spanish. De facto then, the language of international sociology is English, the language of international economics and the United States. Even if compensatory attempts are made to expand the international pool of authors (by accepting submissions in multiple languages) and readers (by providing abstracts of published articles in multiple languages), there is nevertheless a general hegemonic privilege granted to the West, and to the Anglo-American world in particular.

While the globalizing aspirations of these two journals are limited in their practical realization, some editors have taken steps to ameliorate the situation. For example, under Jennifer Platt's tenure as book review editor of International Sociology, there was a policy of making all reviewing crossnational (Platt 2001). Martin Albrow's editorship of International Sociology (1984-1990) was also important in publishing theories and analyses of the logic of indigenization (Albrow 1987, see especially the 1988 issue Volume 3, Number 2). Albrow also published material on the relative provincialism of sociology in the United States and England (Armer 1987). Observations of Eurocentrism continue to appear in International Sociology (Quijano 2000; Kozlarek 2001; Ar-

14. For a more extended treatment of globalization and the problem of English-language hegemony, see Macedo, Dendrinos, and Gounari (2003). 
jomand 2006; Alatas 2007; Zaidi 2007; Schutte 2007; Talmud 2007), although not without ongoing conversation and challenge (Archer 1991; Hall 2001).

Both ISA journals have also recently launched initiatives to address these continuing concerns about the nature of global sociology. In 2001, Current Sociology began publishing an additional two issues each year, devoted to monograph issues. These provide an opportunity for research committees, and national and regional associations to publish edited collections from their conferences, and to publicize their activities in one of the official ISA journals. In 2006, International Sociology also began publishing an additional two issues each year, devoted to book reviews. Devorah Kalekin-Fishman, the editor of these new issues, expressed their decidedly global aspirations in the initial call for papers announcing that "[t]he launching of two bi-annual issues of International Sociology - Review of Books is no less than a bid to rekindle the sociological imagination by proclaiming that sociology as a science is "going global" (http://www.ucm.es/info/isa/publ/isrb.htm). While remaining consistent with the linguistic practices of the journal - publication in English, with abstracts translated into French and Spanish - the Review of Books is committed to a discussion of books published in languages other than English, and also to publishing review essays that compare English and non-English books that are focused on similar topics. The journal also promises to publish review essays that describe the "state of the art" in sociology on different continents, as well as articles that describe how classical texts of sociology have been received in different countries.

While the attempts to deal with the Western (and particularly AngloAmerican) hegemony of ISA's communicative outlets are important examples of reflexivity, they point to significant problems with the attempt to create globalizing communicative forms for sociology. ${ }^{15}$ To begin with, the authors who publish in the official journals of the ISA are located overwhelmingly within Anglo-American and European universities, and they write about sociological debates that are of interest in the West. This is more typical of International Sociology than it is of Current Sociology, and is a less accurate description of the special issues devoted to monographs and book reviews, where the distribution of authors is more geographically diverse. On balance, however, despite reflexive attempts to the contrary, the authorship and content of the main ISA journals illustrate the way the global communicative logic tends to reinforce pre-existing structures of privilege and influence.

15. While there are several ways to think about reflexivity as it is used in sociology (Lynch 2000, Burawoy 2005), here we use it in the sense of reconsidering the values, methods, and premises of sociology as it is practiced by sociologists in the world today. 
This tendency of globalizing communicative forms to reinforce existing structures of power becomes even more pronounced if we push the descriptive analysis a little further to consider which articles in ISA's journals are actually being read and cited. In Current Sociology, as of November 1, 2007, all of the most-cited articles and the majority of the most-read articles were written by sociologists from the US or Western Europe. Similarly, in International Sociology, as of November 1, 2007, the majority of the most-read and most-cited articles were written by sociologists from the US and Western Europe. ${ }^{16}$ This numerical preponderance of Western European and US authors also appears in the results of the 1997 ISA survey that sought to identify the ten most influential books for sociologists: all ten books were published by authors from Germany, France, and the United States. Thus, even with a diversity of speakers, the hierarchical attention space within ISA's communicative forums provides a symbolic advantage to those who speak from the dominant spaces. This tendency is reproduced in the official spaces of direct communication, as anyone who has attended an ISA conference can surely attest. In the end, then, the communicative forms of global sociology as they are organized through the ISA are reproducing US and European hegemony.

It is important to note that existing privilege and power are reinforced despite the ISA's serious reflexive attempts to ameliorate the problem. This lends weight to the argument that reinforcing existing power relations is endemic to single-public models of communication (Eley 1992; Fraser 1992). The relationships in other global publics for academic and social scientific exchange appear to appear to bear out this contention.

If we compare the ISA's communicative spaces to other large publics, we find for sociology that International Sociology is 61st among the 94 journals ranked by the Institute for Scientific Information (Thompson Scientific).${ }^{17}$ Not surprisingly, perhaps, the list of the most influential and high impact journals is dominated by American journals, with a few British and European journals as well. While research shows that nonUS scholars tend to read and cite a more geographically diverse set of publications than do US scholars (Altbach 2006), the spaces of greatest visibility in academic sociology often bypass the communicative outlets organized by the ISA altogether, preferring instead the journals, conferences, and publishers of the core hegemonic nations. This trend is even more pronounced when we consider the relationship between sociology and the global public sphere, which is organized in and through global news organizations (see Keane 2003). It is not the voices or the view-

16. These data can be found at http://iss.sagepub.com/

17. Current Sociology is not included among the 94 journals ranked by ISI. 
points of the ISA that are heard in these larger public forums; rather, it is the individual "star" sociologists of Western nations like Anthony Giddens, Ulrich Beck, and Pierre Bourdieu, who for the most part do not participate in the ISA or in any of its communicative spaces.

In this connection, recognizing the centrality of the mass media is an important part of imagining the possibilities of any kind of global sociology. After all, most publics are mediated publics, shaped by the organization and dynamics of the political and journalistic fields at different levels of specificity (Bourdieu, [1994] 2005). This is part and parcel of a connected set of questions about the communicative potential of global sociology more generally: to the extent that sociologists in the US and elsewhere imagine vibrant professional and public sociologies, questions about the nature of sociology's publics and clients are central. These publics and clients necessarily imply a communicative logic. Some important questions include: which publics and clients are imagined for a global sociology? How might such publics be summoned and engaged? What are the forms of mediation through which meanings are made and circulated in these publics? How will the partial and unrealized communicative geography of global sociology enable or constrain the formation of such publics and the exchanges that occur within them? Put another way, what are the communicative conditions under which the relatively autonomous and isolated debates of sociologists can connect to larger public debates about matters of common global concern? ${ }^{18}$

Whatever the answers to these questions prove to be, the present globalizing forms of global sociology are uneven in their practical realization, and reproduce all the hegemonic privileges of dominant powers. At the same time, there is a reflexive awareness of this fact, which is coupled with interesting new practices that may move global sociology in a more inclusive and diverse direction. It is too early to know whether the ambitious goals of the Review of Books (as well as future innovations) will produce significant changes in the actual communicative geography of global sociology. But even in the absence of a communicative transformation, there is something worthwhile in public recognition of the incomplete realization of the idealized image of global sociology, because it serves to denaturalize the power relations within sociology's globalizing publics.

18. Of course the unexamined premise of this question, as it has circulated in the discipline since early in the 20th century, is that sociological knowledge should be communicated to nonacademic publics and clients. There is also a (not uncontestable) implication that such a communication be direct to the public rather than indirect through teaching or writing specialist books for particular publics. 


\section{The Transnational Forms of Global Sociology}

A transnational communicative logic for sociology imagines not one unitary space for global sociological dialogue but many overlapping communicative spaces and networks of various sizes and particularity. It replaces a global, borderless, universal sociological subject with a transnational, bounded, and multiple one. It recognizes without fear the interpenetration of local, national, and transnational cultural forces, which leads to a kind of "cosmopolitanism with provincialism" (Beck 2006:7). In its communicative geography, the transnational vision entails important differences from the globalizing model of sociology. Instead of imagining the creation of new, global, borderless spaces of dialogue, the transnational model imagines a transformation of already-existing and always-already-bounded spaces. Thus, the goal is not to replace existing communicative spaces and institutions with larger, more inclusive global ones; rather, the goal is to recognize the particular and local while at the same time acknowledging that the current transnational movements of people and ideas must result in a new social treatment of difference.

This communicative model has several advantages. First, it recognizes and guarantees the autonomy of smaller, poorer, and/or less prestigious groups and publics. It conceptualizes such groups as linked together in myriad ways, without demanding assimilation to a single, global, sociological, public sphere, understood as a higher, more abstract, unitary space of shared meanings. Compared to globalizing forms, then, transnational forms of communication make it easier to preserve the distinct publics and meanings of local sociological traditions. As a practical matter, an aggressive encouragement of small and focused local publications will ensure the robustness of local publics and their institutions.

A second advantage of the transnational model for global sociology is that it recognizes and draws attention to the empirical diversity of communicative spaces already observable within and across social formations. In particular, it underscores the importance of local, provincial, regional, and national spaces of communication, and suggests a complex, multilayered, comparative research agenda. At the intellectual level, the corollary is to read and engage at all these levels as a way of thinking around and through US dominance in global publics, the dynamics of which we outlined above.

Third, a transnational communicative logic does not privilege national categories and identities in communicative networks, but rather allows for the possibility of a wide array of alternative forms, including global and regional social movements. Thus, a virtue of the transnational model is that it replaces an either/or logic (i.e., either national or global) 
with a both/and orientation (national and transnational) that is attuned to the ways that the national itself has been fundamentally transformed (see Beck 2006, esp. pp. 81-83). The project of a transnational global sociology is not concerned primarily with the ways that the ISA and its communicative spaces can be opened up to new voices and viewpoints to represent a fuller geographical diversity - although it would certainly recognize the importance of this goal. Rather, the focus of a transnational global sociology would be to encourage developments that help to make existing local, regional, and national associations (including their journals and other communicative outlets) more transnational in their orientation.

A more fully realized transnational agenda would routinely engage with transnational themes, questions, and research agendas as criteria for the selection of papers and topics in journals ${ }^{19}$; solicit editorial membership from several national and local traditions; and encourage transnational engagement across regions and centres as part of professional graduate training and ongoing intellectual practices. One way to assess the success of such an agenda is to ask of any specific journal, conference, or website: to what degree does this communicative outlet engage nonlocal sources and comparisons? This might be measured in the first instance by the origins of citations in bibliographies. More substantially, such an assessment would ask: what are the origins and ongoing contexts of the fundamental categories in which a problem or issue is conceptualized?

As these examples suggest, the normative concerns of the transnational model of global sociology are fundamentally different than those of the globalizing model. Even in its most ambitious versions, the globalizing forms of global sociology are premised on expanding the number of different national voices with access to the international space, while attending to the problems of hegemony endemic to that international space. From a transnational perspective, however, the problem with the globalizing logic is that the conceptual pairing of national-international creates a closed system, where the vision of international diversity tends to hypostatize the national. The result is a project whose conceptual logic glosses over the points of difference and hybridity that exist within the national itself.

The transnational vision is evident in some of the reflexive attempts by the editors of International Sociology to represent diverse voices in their Review of Books project. Consider the competing and potentially contradictory goals of the project. On the one hand, there is an attempt

19. One example of such a transnational orientation might be the current choice of the Canadian Journal of Sociology to publish a special issue on global sociology. 
to provide a forum for publicizing the "state of the art" in a particular nation - a project clearly motivated by the globalizing communicative logic of increasing the diversity of viewpoints and voices within the global public of world sociology. On the other hand, there seems to be a more transnational orientation in publishing articles that consider how canonical texts of sociology are received in different countries. The transnational logic is most apparent in the language used to describe this initiative in the journal's initial Call for Papers:

Considering that many sociologists throughout the world have received their professional training in Western schools, a reflexive confrontation between what students were taught and what researchers encounter in their own locales can lead to rich theoretical insights. (http://www.ucm. es/info/isa/publ/isrb.htm)

This formulation clearly recognizes the need to understand the transnational movement of people and ideas from peripheries to centres and back to peripheries. Such a strategy could be extended further by including articles that examine what happens when the centre becomes transnationalized. This would enable an interesting explanation of the asymmetrical power relationships that arise within transnational publics.

Importantly, in a fully realized transnational space, cultural hybridization will begin to react back on the host population, as the logic of assimilation (i.e., incorporation into the larger space) is replaced by a desire to learn from and incorporate the distinctive talents and cultural knowledge of the transnational population..$^{20}$ As Beck (2006: 64) observes, these kinds of changes are already well underway, as "[b]ehind the façade of enduring nationality ... processes of transnationalization are everywhere taking place." In the dominant regions of the world, the cultural landscape is increasingly disjunctive, the outcome of multiple and simultaneous processes of homogenization and heterogenization (Appadurai 1996).

These processes of transnationalization clearly influence the dominant communicative spaces of sociology throughout the world. In the United States, for example, the editorial boards and the authors of all of the major journals have taken on a transnational character with more participation by sociologists from foreign universities; more participation by sociologists who emigrated to the US for their graduate training and were subsequently employed by American universities; and more participation by sociologists who are actively engaged in research on transnational topics. The same is true of the leadership of the American

20. Beck's (2006:63-64) discussion of the Hmong diaspora is of particular interest in this regard. 
Sociological Association and the faculty composition of the leading research departments, where there are clear processes of transnationalization under way. Nor is the United States alone; similar developments are evident in England, Canada, Australia, and throughout Western Europe.

To say that the dominant sociological spaces are becoming more transnational means more than just the fact that the top journals and the top departments are becoming more international; it also means that there is a more regular communicative engagement with transnational social networks. Clearly, the transnational project has been aided by the advent of popular, comparatively cheap, mass communication based in wireless satellite technology which, in a few short years, has significantly reduced the cost of high-speed media connection around the world. The literature on diaspora provides some useful clues about how to think about the cultural changes that have taken place. Take for instance, Appadurai's cab-driver (1996:4): a Pakistani immigrant listening to sermons broadcast from a mosque in Iran or Pakistan on a radio in the front seat of the cab he drives for a living in Chicago. Or, consider the Vietnamese graduate student in Australia, following Asian news online everyday before she starts research. Or take the academic tenured in Canada who spends her sabbatical in Toronto but actually lives most of the time in Uganda where she also holds a job. Each of these examples point to the growing importance of networks of meaning that follow a transnational logic; that is, these movements of people and ideas describe public spheres in which meanings circulate within, across, and through the boundaries of the nation-state and its bureaucratically ordered institutions. It is not that boundaries cease to matter. They surely do; but the communicative logic that shapes these networks of meaning are organized in ways that are only tangentially connected to, rather than fully determined by, the nation-state system, or by the putative need to organize all of these "national" perspectives within a single global public.

By pointing to the transnational transformation taking place within the dominant communicative spaces of world sociology, we want to be careful not to paint a picture that is one-sidedly optimistic. After all, the changes do not necessarily change the hegemonic status of these spaces, nor is it more likely that they will increase their engagement with smaller and more marginal sociological publics. In fact, if there is not an increase in engagement with different kinds of publics, the transnationalization of the centre will actually increase the hegemony of the dominant publics.

A transnational sociology, rooted in multiple centres of excellence and engagement, ideally would allow these different spaces to intersect in ways that ensure maximal and mutual intellectual enrichment. The fundamental idea here is that more boundaries to cross and more per- 
spectives to engage - basically, more edges and margins involved in the making of meaning - will increase creativity, innovation, and imagination. This is an idea with a long history from Mann's (1986) idea of the interstitial conditions of social innovation to Appadurai's (1996) faith in social creativity, to McLaughlin's (2001) analysis of optimal marginality. A practical agenda to enhance transnational forms of sociological communication must be based on a detailed analysis of the local relationships and institutional contexts (political, economic, cultural/intellectual) of particular sociologies, in particular institutions, cities and other locales, provinces, states, regions, and nations. This approach requires empirical analyses of local sociologies and their clients and publics, suggesting a broadly comparative framework. Such analyses must ask: what are the communicative conditions under which local meanings are preserved when publics and networks of meaning intersect? How is it possible to set up exchanges that are not structured by existing global power relations? How is it possible to connect these kinds of transnational publics to other kinds of publics - including those that are informed by a more globalizing communicative logic, as well as those that are organized around a more defensive and protective nationalizing logic? Answering these questions should provide us with some clues about the practical realization of the transnational vision.

\section{Conclusion}

Currently, there is evidence that both global and transnational logics shape communication in the sociological tradition. As we have tried to suggest, both models entail tradeoffs between the local and global, separation and solidarity, aspiration and practice. The questions we are left with are institutional and empirical: what kind of institutional arrangements enable or constrain global or transnational logics of sociological communication in different parts of the world? And, in either globalizing or transnational logics, what kind of institutional arrangements enable or constrain equitable exchange among sociologists and sociological traditions in different parts of the world? How do participants in the sociological tradition summon publics and clients in different places? Finally, what do these differences tell us about the possibilities of the sociological tradition for the future?

We conclude our "precautionary empirical analysis" of the globalizing and transnational forms of global sociology with a few general observations. First, the practical efforts of the International Sociological Association to establish a globalizing sociology have resulted in the ef- 
fective integration of sociological practice worldwide through a number of specific communicative spaces - most notably, conferences and journals. Here, there is a common attention space where sociologists can discover cutting-edge sociological research from all corners of the globe, and what theories and research topics are setting the global agenda for sociology. At the same time, though, the full realization of this normative vision is limited by several empirical factors. One factor is that the time interval in which global sociology operates is relatively long-term, ranging from a few months for journals to several years for conferences (Albrow 1987). There is as yet no effective institutional mechanism for circulating a global sociology within a shorter time interval. Another factor, and probably the more significant one, is the fact that these communicative spaces are in competition with other forums, more globally influential but far less globalizing in their organization. The ISA journals compete against American, British, and European journals with more international prestige and influence. The World Congress of Sociology must compete against the conferences of the largest and most prestigious national associations, or at least convince sociologists to attend both the World Congress and their national conference. These facts tend to reproduce the privileges of the larger and more powerful national associations.

However, the large and powerful national associations are becoming increasingly transnationalized. Their journals, their sociology departments, and their associations' leadership positions are increasingly occupied by scholars drawn from all over the globe. These scholars take advantage of communication and transportation technologies to remain engaged in a variety of national, regional, and local contexts. As a result, their research interests have a decidedly transnational and hybridizing character, which brings centre and periphery into ever closer contact. The empirical limits of this process primarily revolve around the extent to which this is a movement from periphery to centre and back to the periphery, or just from periphery to centre. In other words, to what extent are these transnationalizing forms producing an actual engagement both cultural and institutional - with smaller and more marginal sociological publics? And what do such changes portend for the disciplinary future of sociology?

On this point of the disciplinary future, we would like to acknowledge a final question which we cannot here answer fully: to what degree is the idea of sociology as a modern professional discipline implicated in the political economy and cultural structures of the modern colonial and neocolonial projects which gave rise to the modern state system and the hegemony of the US within it - including the disciplinary hegemony 
of US sociology? We believe this is a large and important question for sociology and the social sciences (including history and journalism), as well as for the modern disciplined academic field as a whole.

Here we offer the following observation to disciplinary critics who postulate a transdisciplinary or even a postdisciplinary future for knowledge..$^{21}$ Disciplines, like most intellectual projects, have both universalizing and particularizing modes. In the current analysis, this is our distinction between global and transnational communicative forms. These forms shape how any specific sociologist sees and knows the world of knowledge. So, for example, most disciplinary actors distinguish national and regional versions of their own disciplines; most sociologists can distinguish between US, Canadian, British, French, or even European sociology. However, they tend to universalize and homogenize other disciplines, referring to economics or cultural studies as single, global, undifferentiated disciplines. Few sociologists could distinguish German, Japanese, or Mexican economics. Our colleagues in cultural studies could not make precise distinctions between British, Indian, and Canadian sociologies. This mundane observation is a useful starting place for thinking about the role of disciplines in global intellectual communication, and especially the challenges of transdisciplinary and postdisciplinary projects.

One way of reading the transdisciplinary project is as an exemplar of a globalizing logic of communicating about knowledge. In one reading, at least, transdisciplinary and postdisciplinary projects seek to communicate about knowledge beyond disciplinary borders, providing a new unified space for knowledge. In contrast, projects for interdisciplinarity might be understood as closer to the transnational communicative logic outlined above - border crossing concerned with preserving and guaranteeing the specificity of local disciplinary publics and traditions. Arguably, this is true in some versions of transdisciplinary talk too (Lawrence and Déprés 2004). From the perspective of communicative geography then, the question raised by the transdisciplinary project is not whether academic disciplines like sociology are overly narrow or historically played out, but rather what are the communicative logics for exchange and dialogue on this increasingly interconnected, unequal, yet anxious globe.

21. These are contested terms. For a discussion of transdisciplinarity, see Lawrence and Déprés (2004). We use these terms here to refer to the project to unify knowledge and supersede disciplines. In this connection then, we might include some of the arguments made about the "dubious" social science disciplines by foundational thinkers in global sociology like Immanuel Wallerstein (2004; also Wallerstein et al. 1996). 


\section{REFERENCES}

Abaza, Mona and Georg Stauth. 1988. Occidental reason, orientalism, Islamic fundamentalism: A critique. International Sociology 3(4):343-364.

Akiwowo, Akinsola. 1999. Indigenous sociologies: Extending the scope of the argument. International Sociology 14(2):115-138. 1988. Universalism and inigenisation in sociological theory: Introduction. International Sociology 3(2):155-160.

Alatas, Syed Farid. 2007. The historical sociology of Muslim societies: Khaldunian applications. International Sociology 22(3):267-288.

Albrow, Martin. 1987. Sociology for one world. International Sociology 2(1):112.

Alexander, Jeffrey C. 2006. The Civil Sphere. New York: Oxford.

Altbach, Philip. 2006. The tyranny of citations. Inside Higher Education 43:35.

Appadurai, Arjun. 1996. Modernity at Large. Minneapolis, MN: Minnesota University Press.

Archer, Margaret. 1991. Sociology for one world: Unity and diversity. International Sociology 6(2):131-147.

Arjomand, Saïd Amir. 2006. Civilizations in dispute: Historical questions and theoretical traditions; axial civilizations and world history. International Sociology 21(3):393-399.

2000. International sociology into the new millennium: The global sociological community and the challenge to the periphery. International Sociology 15(1):5-10.

Armer, J. Michael. 1987. Provincialism and internationalism in contemporary American sociology. International Sociology 2(3):315-324.

Bauman, Zygmunt. 2002. Society Under Siege. Malden, MA: Polity Press.

Beck, Ulrich. 2006. Cosmopolitan Vision. Malden, MA: Polity Press.

Benhabib, Seyla, 1996. Democracy and Difference: Contesting the Boundaries of the Political. Princeton, NJ: Princeton University Press.

Bourdieu, Pierre. [1994] 2005. Political, social science, and journalistic fields. Pp. 29-47 in Rodney Benson and Erik Neveu, eds., Bourdieu and the Journalistic Field. Cambridge: Polity Press.

Burawoy, Michael. 2005. 2004 presidential address: For public sociology. American Sociological Review 70(1):4-28.

Calhoun, Craig. 1992. Introduction: Habermas and the public sphere. Pp. 1-50 in C. Calhoun, ed., Habermas and the Public Sphere. Cambridge, MA: The MIT Press.

Cardoso, Fernando H. 1986. Foreword. International Sociology 1(1):1-2. 
Chase-Dunn, Christopher. 2005. Global public social science. The American Sociologist 36(3-4):121-132.

Cohen, Jean and Andrew Arato. 1992. Civil Society and Political Theory. Cambridge, MA: The MIT Press.

Dayan, Daniel and Elihu Katz. 1992. Media Events. Cambridge, MA: Harvard University Press

Dhaouadi, Mahmoud. 1990. Ibn Khaldun: The founding father of eastern sociology. International Sociology 5(3):319-335.

Eley, Geoff. 1992. Nations, publics, and political cultures: Placing Habermas in the nineteenth century. Pp. 289-339 in C. Calhoun, ed., Habermas and the Public Sphere. Cambridge, MA: The MIT Press.

Fraser, Nancy. 1992. Rethinking the public sphere: A contribution to the critique of actually existing democracy. Pp. 109-142 in C. Calhoun, ed., Habermas and the Public Sphere. Cambridge, MA: The MIT Press.

Gareau, Frederick H. 1988. Another type of third world dependency: The social sciences. International Sociology 3(2):171-178.

Garnham, Nicholas. 1992. The media and the public sphere. Pp. 359-376 in C. Calhoun, ed., Habermas and the Public Sphere. Cambridge, MA: The MIT Press.

Gilroy, Paul. 2004. Postcolonial Melancholia. New York: Columbia University Press.

Gutmann, Amy and Dennis Thompson. 1996. Democracy and Disagreement. Cambridge, MA: Harvard University Press.

Habermas, Jürgen. 1989 [1962]. The Structural Transformation of the Public Sphere, transl. Thomas Burger. Cambridge, MA: The MIT Press 1996. Between Facts and Norms: Contributions to a Discourse Theory of Law and Democracy. Cambridge, MA: The MIT Press.

Hall, John A. 2001. Confessions of a Eurocentric. International Sociology 16(3):488-497.

Jacobs, Ronald N. 2000. Race, Media, and the Crisis of Civil Society: From Watts to Rodney King. Cambridge: Cambridge University Press.

Keane, John. 2003. Global Civil Society? Cambridge: Cambridge University Press.

Klein, Julie Thompson. 2005. Humanities, Culture, and Interdisciplinarity: The Changing American Academy. New York: State University of New York Press. 1990. Interdisciplinarity. Detroit: Wayne State Press.

Kozlarek, Oliver. 2001. Critical theory and the challenge of globalization. International Sociology 16(4):607-622. 
Kurasawa, Fuyuki. 2004. A cosmopolitanism from below: Alternative globalization and the creation of a solidarity without bounds. European Journal of Sociology 45:233-255.

Lawrence, Roderick J. and Carole Désprés. 2004. Transdisciplinarity. Futures 36(4):397-526.

Loubser, Jan J. 1988. The need for the indigenisation of the social sciences. International Sociology 3(2):179-187.

Lynch, Michael. 2000. Against reflexivity as an academic virtue and source of privileged knowledge. Theory, Culture, and Society 17(3):26-54.

Macedo, Donald, Bessie Dendrinos, and Panayota Gounari. 2003. The Hegemony of English. Boulder, CO: Paradigm Press.

Mann, Michael. 1986. The Sources of Social Power. Volume 1. Cambridge: Cambridge University Press.

McLaughlin, Neil, Lisa Kowalchuk and Kerry Turcotte. 2006. "Why Sociology Does Not Need To Be Saved: Analytic Reflections on Public Sociologies" The American Sociologist 36(3-4): 133-151.

McLaughlin, Neil. 2001. Optimal marginality: Innovation and orthodoxy in Fromm's revision of psychoanalysis. The Sociological Quarterly 42(2):271-288.

Ong, Aihwa and Stephen J. Collier, eds. 2005. Global Assemblages: Technology, Politics, and Ethics as Anthropological Problems. Malden, MA: Blackwell.

Park, Peter. 1988. Toward an emancipatory sociology: Abandoning universalism for true indigenisation. International Sociology 3(2):161-170.

Platt, Jennifer. 2007. Transatlantic voyages and national sociologies. Paper presented at Transatlantic Voyages, The International Congress of Sociology, University of Nancy 2, May 31-June 1, 2007. 2001. Book review progress report. International Sociology 16(2):241245. 1998. History of the ISA 1948-1997. International Sociological Association.

Quijano, Aníbal. 2000. Coloniality of power and Eurocentrism in Latin America. International Sociology 15(2):215-232.

Sanda, A. Muyiwa. 1988. In defence of indigenisation in sociological theories. International Sociology 3(2):189-199.

Schutte, Gerhard. 2007. Looking to the future: Crossing disciplinary borders in South Africa. International Sociology 22(5):564-567.

Talmud, Ilan. 2007. The handbook of economic sociology (review). International Sociology 22(2):175-178.

Thompson, John B. 2005. Books in the Digital Age. Malden, MA: Polity Press. 
Wallerstein, Immanuel. 1974. The Modern World System. New York: Academic Press.

2004. Anthropology, sociology, and other dubious disciplines. Pp. 166190 in The Uncertainties of Knowledge. Philadelphia, PA: Temple University Press, .

Wallerstein, Immanuel, Calestous Juma, Evelyn Fox Keller, Jürgen Kicka, Dominique Lecourt, V.Y. Mudimbe, Kinhide Mushakoji, Ilya Prigogine, Peter J. Taylor, and Michael-Rolph Trouillot. 1996. Open the Social Sciences: Report of the Gulbenkian Commission on the Restructuring of the Social Sciences. Stanford, CA: Stanford University Press.

Young, Iris Marion. 2000. Inclusion and Democracy. Oxford: Oxford University Press.

Zaidi, Ali Hassan. 2007. A critical misunderstanding: Islam and dialogue in the human sciences. International Sociology 22(4):411-434.

Ronald Jacobs is an Associate Professor of Sociology and Director of Graduate Studies at The University at Albany, New York, USA. Recent publications include "From Mass to Public: Rethinking the Value of the Culture Industry" in Culture in the World, vol. 1: Cultural Sociology and the Democratic Imperative (2007) and "Narrative and Legitimacy: US Congressional Debates about the Nonprofit Sector" co-authored with Sarah Sobieraj in Sociological Theory (2007).

Eleanor Townsley is an Associate Professor of Sociology at Mount Holyoke College in South Hadley, Massachusetts, USA. Recent publications include "The social construction of social facts: Using the US Census to examine race as a scientific and moral category," Teaching Sociology (2007) and "The public intellectual trope in the United States," The American Sociologist (2006). 